\title{
Execution of Sentence of Life Imprisonment in Albania, in Violation of Fundamental Human Rights
}

\author{
Esmeralda Thomai \\ Lawyer near Tirana Bar \\ PhD Candidate, Department of Law (Penal science), SEEU University, Macedonia \\ Email: esmeraldathomai@yahoo.com
}

\section{Doi:10.5901/mjss.2017.v8n1p169}

\begin{abstract}
The goal of this article and of the analysis itself on which it is based, is to identify weaknesses in penitentiary legislation in force in the Republic of Albania, in order that the penal policy of the Albanian state, should respect the principles on which will be based to be effective. At the end of 2015 the number of persons who have been sentence to life imprisonment in Albanian prisons has been 159 people, convicted in 2895 of the total prison who were serving a sentence in Albanian prisons. The number of those sentenced to capital punishment has increased, compared with the statistics of 3-4 years ago. Albanian law on the punishment of life imprisonment presents serious problems in the modalities of execution of the punishment, violating the right and fundamental freedom of man, that lives in liberty, and break up the Article 3 of the ECHR, which prohibits placing under cruel punishments, inhuman and degrading. The Republic of Albania will need as soon as possible to change its legislation concerning the category of persons sentenced to life imprisonment. Condemned to life imprisonment, according to each individual case and referred to progress in the sentence, in view of the disappearance of the potential for recidivism and in view of correction, after the expiry of a time limit prescribed by law,they should have the right and opportunity in court jurisdiction to address the real execution of criminal sentences for the benefit of supervised freedom or conditional one. In this way, the hope of life again in freedom, will make the convicts to life imprisonment interested to educate themselves, by all the values that will be in accordance with social rules.
\end{abstract}

Keywords: Conditioned freedom, Instruments of International Law, Execution.

\section{Introduction}

As in most European countries, in the Republic of Albania, the sentence of life imprisonment is prescribed by criminal legislation as the most severe punishment. In principle, the pronunciation of life imprisonment as a sanction for serious offenses, brings the individual isolation from society "for life" forever deprivation of civil rights and often in the literature is designated as the "civil death". Republic of Albania in the number of prisoners, according to statistics of March 2016 from the General Directorate of Prisons, is in total 2596 persons. From these convicted, 158 people suffer the maximum sentence under the Criminal Code, that life imprisonment. ${ }^{1}$

\section{Sentence to life imprisonment in Albania, in terms of gaining conditioned freedom}

The number of those sentenced to capital punishment has increased, compared with the statistics of 3-4 years ago. In December 2012 the number of persons sentenced to life imprisonment in Bangladesh, who have been serving in Albanian prisons this sentence has been 141 persons from 2792 sentenced to imprisonment that were in these places, and in December of 2015, this number went from 2895 to 159 persons sentenced to imprisonment.

The following table presents the annual statistic:

\begin{tabular}{|l|l|l|}
\hline Month, year & $\begin{array}{l}\text { In total,Sentenced to imprisonment serving } \\
\text { a sentence in an institution }\end{array}$ & $\begin{array}{l}\text { Sentenced to life imprisonment serving } \\
\text { a sentence in an institution }\end{array}$ \\
\hline December 2012 & 2792 & 141 \\
\hline December 2014 & 2727 & 149 \\
\hline December 2015 & 2895 & 159 \\
\hline
\end{tabular}


The average age of this category of prisoners is about 40 years.. ${ }^{2}$

Albanian legislation does not allow release on parole for convicts to life imprisonment. The current penal code forbids this in his article 65 of which states: "not allowed to release on parole for the convicted to life imprisonment" Under paragraph. "2" of this article, "only in exceptional cases" of convicted to life imprisonment can be released on parole when he suffered no less than 25 years and during imprisonment has had excellent behavior, referring whose, estimated that the purpose of punishment is to achieve its education"3

\section{Literature Review and Hypotheses}

Albanian criminal legislation does not specify which are exceptional cases, to legitimize a convicted to life imprisonment, after 25 years in prison, to seek release. It was left to discretion of the court, which determines whether there are judicial proceedings "exceptional cases" to enable the provision of freedom for this category. Practically no cases were referred to court to see what is related to exceptional circumstance court in a quest for freedom provided by life imprisonment.

Competent authority to set earlier "on parole" to persons sentenced to imprisonment in the Republic of Albania is the country's Court of execution of sentence 4 .

Albanian judicial practice since 1998 when the death penalty was abolished by the Criminal Code, it is not so far recorded any case, that a lifer, have gained conditional freedom.

Because of the existence of Article 65 of the Code, which prohibits in principle "on parole" sentence of convicted persons ever, it can be said that it is very unlikely that a person sentenced to life imprisonment by a final judgment in the Republic of Albania could then leave the prison.

This is in contrast with new educational purpose of punishment in modern criminal law.

In his work on "crime and punishment" published in 1764, Cesare Beccaria wrote, "knowing that you could never be a free man, only when you die, is even more cruel is a" slavery penalty "5.

To see whether, the prohibition under Article 65 of the Albanian Penal Code is in harmony with the instruments of international and European and whether or not in accordance with the standards of the European Convention on Human Rights, will have to stop in these instruments and jurisprudence of the European Court of Human Rights, but firstly receiving information about the possibility of releasing from life imprisonment in some European countries

\subsection{European instruments regarding the sentence to life imprisonment}

Starting since 1976 the Committee of Ministers of the Council of Europe has adopted a number of resolutions and recommendations concerning prisoners with life sentences and those sentenced to prison for a long time.

\subsection{Resolution no. (76) 2 of 17 February 1976 "On the treatment of prisoners for a long time" obliges member of states} by defining: "States should:

1. Pursue a criminal policy under which long prison sentences should be applied only when is estimated necessary for the protection of society;

2. To adopt appropriate legislative and administrative nature to favor a suitable treatment during the execution of these penalties;

3. To ensure that the cases of all prisoners to be reviewed and to be seen if any prisoner can be accorded conditional release ;

4. To grant prisoners "on parole"after the expiry of a time limit, and take into account that only general social deterrence as purpose of punishment can not justify a refusal to be given conditional freedom to prisoners.

5. To adopt for the category of persons with sentenced to life imprisonment by the same rules that apply for convicts with long prison.

6. To provide for convicts of life imprisonment and those who sentenced long prison periodically every 8 or 14 years, an examination of the case ,in order to see if prisoners can be accorded conditional release.

\footnotetext{
${ }^{2}$ Statistics of the General Directorate of Prisons, Tirana 2016

3Law no. 7895, dated 27.01.1995 "The Criminal Code of the Republic of Albania"Changed

${ }^{4}$ Article 477 of the Criminal Procedure Code

${ }^{5}$ Cacace Lorena "Ergastolo in Italia, In Europa e nel mondo: a cosa serve ancora il carcere a vita? " Art.24.10.2014 Nano Press.
} 


\subsection{Recommendation no. 22 Council of Europe, dated 24 September 2003 for member states concerning conditional} release.

This recommendation has to do with conditional release from imprisonment. In this recommendation adhere a set of rules which relate to the preparation for release "on parole", the conditions under which prisoners should be placed, the procedural guarantees should be respected.

According to paragraph 3 of this Recommendation, ".... "on parole"release will need to help offenders overcome transition from prison life to life in the community through the establishment of the terms and implementation of the measures after release, contributing to public safety and reduction of delinquency within the society. Paragraph 4.a "foreseen:" .... to reduce the harmful effects of imprisonment, the legislation should provide the opportunity for all prisoners, including those with life imprisonment benefit from "on parole"release. ${ }^{6}$

\section{Methodology and Research Goal}

Recommendation No. 23 of the Committee of Ministers of the Council of Europe dated 09.10 .2003 to member states on the management by the penitentiary administration of persons sentenced to imprisonment life and those sentenced to imprisonment in the long run.

This recommendation defines the that ".... The execution of sentences that deprive prisoners of their liberty, means finding a balance between respect for order and discipline in the penitentiary institutions on the one hand and the need to offer prisoners a dignified life conditions and an active regime, a constructive preparation for their release".7

Among the basic principles and rules which relate to the treatment of this category of prisoners, Recommendation 23 , we find the principle of individualization, which consists in taking into account the individual characteristics of the personality of the prisoners to keep them in mind for the adaptation individual plans of the sentence and the principle of progression, which dictates the need for individualized treatment plan of the sentence of life imprisonment or imprisonment for a long time a prisoner, be such as to provide an evolution about through the progressive penitentiary system (see para. 3 and 8 of the Recommendation).

Paragraph 10 provides that individual plans of carrying out the sentence of life imprisonment or imprisonment for long must serve a systematic approach to progressive evolution of prisoners through the penitentiary system conditions progressively less restrictive to a final stage in the which ideally should be transferred within the company, so that prison conditions and rules allow a life respecting the laws and adaptation in the community after conditional release.

Paragraph 16 states that criminal dangerousness and needs are not intrinsically stable characteristics and that there is room to proceed periodically with an assessment of the risks representing or not the convict. Finally, paragraphs 33 and 34 are devoted to preparing for the return of prisoners into society. Under paragraph 33 , to help convicts to life imprisonment or imprisonment for a long time to face the problem of transition from an imprisonment of long life in observance of laws in the midst of society, their release should be sufficiently prepared before taking into account: -the need to implement specific plans dealing with pre release and post release, taking into account relevant risks and needsthe possibility of prosecution after the release of prisoners or treatment programs in which prisoners were involved in serving a sentence of imprisonment. -the need for cooperation of the penitentiary administration, supervisory authorities and the condition during social or medical services. ${ }^{8}$

\subsection{Instruments of International Law}

\subsubsection{Statute of the International Criminal Court in The Hague}

Statute of the International Criminal Court concluded in Rome on July 17, 1998 and approved by the General Assembly of the Organization of the United Nations on June 22, 2001, allows the reduction of the sentence to life imprisonment if the risk of crime and personal situations of prisoners They justify this reduction. Article 3 of the Statute 110 \& determine when sentenced to life imprisonment committed 25 years the Court shall review the sentence to determine whether there

${ }^{6}$ Council of Europe, , $\operatorname{Rec}(2003) 22$ of the Comittee of Ministers to member states on conditional relase

${ }^{7}$ Council of Europe, , Rec (2003)23 of the Comittee of Ministers to member states on the management by prison administrations of life sentence and other long-term prisoners

${ }^{8} I B I D E M$ 
is room to reduce it. ${ }^{9}$

Review criteria and procedures set out in the Rules of Procedure. Under paragraph 4 of Article 110 of this regulation criteria should take into consideration the judicial bodies of the Chamber of Appeal, which has jurisdiction for examining the case for sentence reduction during the execution of his dealing with: - the behavior of prisoners, which should show real detachment from his crime

- the possibilities of rehabilitation and reintegration of prisoners

- the prospect of release prisoners ahead of time not risk falling because of social instability

- taking into account the consequences that may have prematurely release of prisoners connected with the victims and their family member -Personal situation of the convicted person, especially aggravated his state of physical or mental health or his advanced age.

Article 224 of the Rules of Procedure stipulates that in order to apply paragraph 5 of Article 110 of the Statute, the three judges of the Appeals Chamber review the question of reduction of the sentence every three years, unless an interval of less time is determined in a decision taken in application of Article 110 paragraph 3 of the Statute. This article (224) also defines that, if the circumstances have changed significantly, judges can authorize a convicted person to seek a re-examination / review during the three-year period or a shorter interval of time where they will affix. ${ }^{10} \mathrm{As}$ shown, the legal instruments of international criminal law and that European consider life imprisonment not given "forever". This sentence will have to be re examined during the execution phase and prisoners with such sanction could be given an opportunity to be released on conditional freedom.

\section{The jurisprudence of the European Court of Human Rights concerning life imprisonment}

European Court of Human Rights has been asked on several occasions to consider and pronounce a decision to the Grand Chamber of compliance sentence of life imprisonment without possibility of release on parole, with the European Convention on Rights human, which in Article 3 provides: "no one can be placed under torture or penalties or inhuman and degrading treatment".

Some of the most prominent of this jurisprudence, are:

- The issue "Kafkaris against Cyprus" (Grand Chamber decision of February 12, 2008)

- "Vinter and Others against UK" (Grand Chamber decision of July 9, 2013)

- "Öcalan against Turkey "(Decision ofGrand Chamber on 18 march 2014)

- "Trabelsi againstBelgjium" (Decision ofGrand Chamber on 4 september 2014)

- "Murrai againstNetherlands" (Decision ofGrand Chamber on 26 prill 2016)

In its jurisprudence, around 1970 the Strasbourg Court has stated the compatibility of the sentence to life imprisonment with the norms of the Convention, based on the "theory multifunctional sentence" in one aspect, and the other aspect, this Court has recognized freedom parole with the condition of gate,which constitutes the effective reintroduction inmates to life in civil society. Denying that the only function of punishment is rehabilitation, the ECtHR has at this time advocating prevention and social protection through the State's punitive power. ${ }^{11}$

After 2008, when the Strasbourg Court has been asked again in a series of court expressed about the fact, whether life imprisonment without the possibility of parole is an inhuman and degrading treatment, violating Article 3 of the European Convention on Human Rights Human, the Court has had a gradual approach the problem.So:

In the case of "Kafkaris" ECHR approached this problem by referring to the sovereignty of the state in the implementation of penal policy, with its conclusion that it is the prerogative of the criminal policy of the state to determine, terms of a revaluation of the sentence to life imprisonment with a view reducing or terminating it.

In the case of "Vinter" this Court marked a qualitative leap concluding that, for a country it is necessary to provide a mechanism that consists in evaluating the continuity or not the sentence to life imprisonment, a mechanism which will order the release of the convicts, if existing at the moment excuses communication sanction reduced over time and lack motives which will legitimize the detention of prisoners.

\section{Data and Research Methodology in This Research Paper}

Further, in the case of Öcalan, with its finding that the gravity of the offense cannot justify cruelty and degrading

9Statut de Rome, de la Cour Pénale Internationale

${ }^{10}$ Réglement de Procédure et de preuve de la Cour Pénale Internationale

${ }^{11}$ Ranalli Daniela, "L' Ergastolo nella Giurisprudenza della Corte Europea dei Diritti dell' Uomo", Italia, 2015 fq.1 
treatment of prisoners, the Court approached the problem of life imprisonment without the possibility of parole closer, in response to policy offense to those states that still apparently do not find the balance between the general principle of social protection on the one hand and the principle of socialization of the perpetrator from the other side, if indeed there is a possibility for him to be re-socialized.

Finally, the issue "Murray" in 2016 the Court was approached to the problem by reaffirming the position it has held for prisoners in general, according to which, it is the obligation of states to ensure prisoners, even those eternally condemned to prison regimes penitentiary, which are appropriate to the objective of forgiveness, which allow those convicted of making progress in this regard during the sentence. State by the Court, will have to find ways and mechanisms to meet this obligation.

Referring to the jurisprudence of this court can conclude that, according to the Strasbourg Court, the sentence of imprisonment should not remain "forever given",it should not end when a person's life ends. This sentence should be reassessed during the executive proceedings by judicial or administrative authorities of the state.

\section{Critical assessment on the legal aspects of imprisonment executive life in Albania}

Referring, European and instruments of international law,and conventional standards, which the Strasbourg Court has identified in the above decisions, we can say that Albanian law on the punishment of life imprisonment, violates basic human right not to be placed under a punishment inhuman and degrading and the right to life in freedom. Depriving priory, eternally condemned to life imprisonment by the right to freedom, the legal provisions in force treat convicted with a life sentence like "eliminating" from society. He should just wait for death to win "freedom".

In legal terms, the Albanian legislation on the execution of the sentence of life imprisonment is not in accordance with European and international standards.

\section{Analyzing Data}

This legislation needs to be changed and reformed. By it should be lifted prohibitive rates, Article 65 of the Criminal Code does not allow release on parole for convicts to life imprisonment, as a provision which is inconsistent with the Constitution Articles 15 and 17 thereof, and incompatible with the European Convention on Human Right. Legal framework in the execution of sentences to life imprisonment in Albania needs to be changed. Condemned to life imprisonment, according to each individual case and referred to progress while serving a sentence in view of the disappearance of the potential for recidivism and in view of correction, after the expiration of a time limit prescribed by law shall have the right and the real jurisdiction possibility,in order to address judicial execution of criminal, to obtain freedom of supervised or conditional.

"On Parole" for the convicts to life imprisonment should not be won only in exceptional cases,but even these Albanian legislation in paragraph 2 of Article 65 which mentions, are not defined. This provision bans contained in Penal Code since 1995, does not meet the exigencies of the purpose of punishment in criminal law and contemporary addition that contrary to the Convention and the Constitution, is contrary to the principles on which is based criminal policy in a democratic state, such as humanism, individualization of treatment of prisoners, the right to judicial access ... etc.

It is expected that in a large part of the population, in the eventuality of discussion and political efforts to favor freedom of conditional convicts to life imprisonment would be against, based on the reasoning that dangerous criminals will be kept isolated forever, as far as they do not adopt to social rules.

But Republic of Albania in Constitutional provisions is determined that: Article 17 "New restrictions of rights and freedoms set forth in this constitution may be established only by law for a public interest or for the protection of the rights of others. The restriction must be proportionate to the situation that has dictated it. These limitations may not infringe the essence of freedoms and rights and in no case may exceed the limits set forth in the European Convention on Human Rights".

Article 15"Rights and fundamental freedoms are indivisible, inalienable and inviolable and stand at the basis of the entire juridical order. The organs of public state, in fulfillment of their duties, must respect the rights and fundamental freedoms, as well as contribute to their realization".

Although the Constitution of the Republic of Albania is not foreseen a specific provision which determine the purpose of execution of criminal penalties as was done in Italy, Spain .... etc with the formulations: "Penalties depriving liberty and security measures will be directed at social rehabilitation and re-socialization .120r"Punishment can not consist

${ }^{12}$ Article 25.2 of the Spanish Constitution, in force since 27.12.1978 
in treatment contrary to the sense of humanity and must aim at rehabilitating the condemned" 13the abovementioned constitutional provisions, Articles 15 and 17 of the Constitution in the Republic of Albania; fully justify the conclusion according to which Article 65 of the Albanian Penal Code prohibiting the possibility for the release of prisoners to life imprisonment is in contrary to the Constitution.

Also, although it is not made in the evaluation constitutional existence of Article 65 of the Criminal Code, Albanian politicians should have the courage to take the legislative initiative to repeal this article and the creation of a legal framework for the respect of fundamental rights and freedoms of category the persons sentenced to life imprisonment.

Every man, even if sentenced to an extreme measure, should be returned to the personal dignity of life and in hope of freedom. The existence of this provision in the Criminal Code (Article (65), install a regime penitentiary only punitive and vindictive on the modalities of its application. This rate is in itself the break of the state of law, suspend treatment penitentiary or interrupts the performance progressive rehabilitation and social reintegration that should guide any prison sentence.

Albania remains behind developments in the field of criminal law. Today in Europe a debate, whether or not there should be criminal to life imprisonment legislation. This debate is intensifying these days in European countries with developed democracy and includes views on considerations on punishment and its purpose, but because of the intensification of the debate are the findings of the jurisprudence of the European Court in Strasbourg, which has a indisputably merit to be a promoter of political movements that change lives and to prioritize human and personal dignity.

\section{Conclusions}

Sentence to life imprisonment in the Republic of Albania is applied by the Special Section of the Criminal Code for serious offenses, with major social risk that comes from the abolition of the death penalty from the Criminal Code in 1998. At the end of 2015 the number of persons who have been keeping this kind of punishment in Albanian prisons was 159 people. Ranked among the European countries that apply capital punishment, Albania has in force in its Criminal Code a provision that prohibits conditional freedom of this category of prisoners during the executive phase of the criminal proceedings.

The question whether it is fair and human that such persons are considered delinquent by final judgment of the court, to stay until the end of life in penitentiary institution, focuses attention on the necessity of carrying out an objective analysis, whether it is constitutional and in accordance with European standards of human rights and fundamental freedoms, the fact of standing behind prison bars forever, until the end of life of these people, part of our society.

The purpose of this paper and of the analysis itself on which it was based, at identifying weaknesses penitentiary legislation in force in the Republic of Albania, in order that penal policy should respect the principles on which will be based to be effective.

Referring to the European instruments and those of international law,

and conventional standards, which the Strasbourg Court has identified in its decisions after 2011, we can say that national legislation concerning the sentence of life imprisonment presents serious problems in the modalities of execution of the punishment, violating the right and basic human freedom, that of life in freedom and at the same time violating Article 3 of the ECHR, which prohibits placing under inhumane punishments, inhuman and degrading. Not taking the initiative for the abolishment of the capital punishment as some European countries (Norway, Portugal, Serbia, etc.)has done, at least, Albania will need to quickly change its legislation concerning the category of prisoners with life imprisonment.

Prisoners condemned to life imprisonment, according to each individual case and referred to progress in the sentence, in view of the disappearance of the potential for recidivism and in view of correction, after the expiration of a time limit prescribed by law shall have the right and opportunity in court jurisdiction to address the real execution of criminal sentences for the benefit of supervised freedom or conditional one. In this way, the hope of life again in freedom, will make the convicts to life imprisonment interested to educate themselves, with the values that will be in accordance to social rules.

\section{References}

Cacace Lorena "Ergastolo in Italia, In Europa e nel mondo: a cosa serve ancora il carcere a vita? " Art. 24.10.2014 Nano Press. Council of Europe, Comittee of Ministers, Resolution (76)2), 17 February 1976

${ }^{13}$ Article 27 (2) of the Constitution of the Republic of Italy, in force since 01.01.1948 
Council of Europe, , Rec (2003)22 of the Comittee of Ministers to member states on conditional relase

Council of Europe, , $\operatorname{Rec}(2003) 23$ of the Comittee of Ministers to member states on the management by prison administrations of life sentence and other long-term prisoners

European Cimmittee for the Prevention of Torture and Inhuman or Degrading Treatment or Punishment, Strasbourg 27 June 2007 , "Actual/Real life sentences"

Halissat Ismaël, Art. “ La Perpétuité réelle existe-t-elle en France?” Le Monde, 12.01.2016

Code of Criminal Procedure of the Republic of Albania

European Convention of Human Rights

The Constitution of the Republic of Italy, 01/01/1948

The Constitution of the Republic of Albania Law no. 8417, dated 21.10.1998

Spanish Constitution, 27 .12.1978

Law no. 7895, dated 27.01.1995 "The Criminal Code of the Republic of Albania"

Law no. 7895, dated 27.01.1995 "The Criminal Code of the Republic of Albania"Réglement de Procédure et de preuve de la Cour Pénale Internationale

Statut de Rome, de la Cour Pénale Internationale

Decisions of the European Court of Human Rights (2011-2016)Wikipedia "Emprisonnement à La Perpétuité"

+31 Mag.NL, Art. " II Punto L ergastolo in Europa. Dove e stato abolito?" 01.04.2016 